\title{
U⿱宀⿻三丨口
}

\section{Cryotherapy and inflammation: evidence beyond the cardinal signs}

Bleakley, C. M., \& Davison, G. W. (2010). Cryotherapy and inflammation: evidence beyond the cardinal signs. Physical Therapy Reviews, 15(6), 430-435. https://doi.org/10.1179/1743288X10Y.0000000014

Link to publication record in Ulster University Research Portal

\author{
Published in: \\ Physical Therapy Reviews
}

Publication Status:

Published (in print/issue): 01/12/2010

DOI:

10.1179/1743288X10Y.0000000014

\section{Document Version}

Publisher's PDF, also known as Version of record

\section{General rights}

Copyright for the publications made accessible via Ulster University's Research Portal is retained by the author(s) and / or other copyright owners and it is a condition of accessing these publications that users recognise and abide by the legal requirements associated with these rights.

\section{Take down policy}

The Research Portal is Ulster University's institutional repository that provides access to Ulster's research outputs. Every effort has been made to ensure that content in the Research Portal does not infringe any person's rights, or applicable UK laws. If you discover content in the Research Portal that you believe breaches copyright or violates any law, please contact pure-support@ulster.ac.uk. 


\title{
Cryotherapy and inflammation: evidence beyond the cardinal signs
}

\author{
Chris M. Bleakley ${ }^{1}$, Gareth W. Davison ${ }^{2}$ \\ ${ }^{1}$ Health and Rehabilitation Sciences Research Institute and ${ }^{2}$ Sport and Exercise Sciences, Research Institute, \\ University of Ulster, Northern Ireland
}

Background: Cryotherapy is one of the most popular electro-physical agents used to 'treat' acute inflammation after a soft tissue injury. Much of the clinical rationale for this is based on anecdotal reports, with most clinicians accepting that cryotherapy has an 'anti' inflammatory effect after injury. There have been a number of recent advances towards improving our understanding of the inflammatory process after soft tissue injury.

Objectives: To review the rationale for cryotherapy intervention in the acute phases of soft tissue injury, whilst considering physiological, cellular and molecular models of inflammation.

Methods: Qualitative review of recent evidence.

Results: Research is restricted to animal models, applying various forms of cryotherapy after induced soft tissue injury. Outcomes focus on the effect that cooling has on key physiological, biochemical and molecular inflammatory events including: secondary cell death, white blood cell behaviour, apoptosis, blood flow and oedema formation.

Conclusion: Cryotherapy can have an influence on key inflammatory events at a cellular and physiological level after an acute soft tissue injury. However, the relative benefits of these effects have yet to be fully elucidated and it is difficult to contextualize within a human model. It is important to continue to update our rationale for applying common electro-physical agents such as cryotherapy after acute soft tissue injury, based on contemporary models of inflammation.

Keywords: Cryotherapy, Acute injury, Soft tissue, Inflammation

\section{Introduction}

Cryotherapy is one of the simplest and oldest modalities for treating soft tissue injuries such as sprains, contusions, and dislocations. The immediate phase after soft tissue injury is characterized by an acute inflammatory response. This often presents clinically with cardinal signs such as heat, redness, pain and swelling. Few clinicians may look beyond these cardinal signs when providing justification for intervention; and it is commonly accepted that cryotherapy has an 'anti' inflammatory effect after soft tissue injury. Applying a cold agent to a hot and red tissue may seem pragmatic; however, there is not always an obvious link between inflammation visible under the microscope and that clinically apparent and characterized by the original cardinal signs. ${ }^{1}$ Paradoxically, recent trends in sports medicine involve delivering growth factors into healing muscle tissue (e.g. via platelet rich plasma or autologous

Correspondence to: Chris Bleakley, Health and Rehabilitation Sciences Research Institute, School of Health Sciences, University of Ulster, Shore Road, Newtownabbey, Co Antrim, BT37 OQB, Northern Ireland. Email: chrisbleakley@ hotmail.com blood injections) $)^{2}$ which seems to lean more towards a pro-inflammatory treatment approach.

Our aim is to review the rationale for cryotherapy intervention in the acute phases of soft tissue injury, whilst considering physiological, cellular and molecular models of inflammation. Where appropriate, relevance to injured human subjects will be assessed, and recommendations for future research provided.

\section{Search Strategy}

In January 2010, we undertook a computerized literature search on Medline, EMBASE and Cochrane Central Register of Controlled Trials (CCTR) (via OVID) using nine key words and subject headings relating to cryotherapy. This was supplemented with 'related article' searches on PubMed, and biblography tracking. Relevant studies were extracted, with exclusions made based on titles, abstracts or full text versions. No restrictions were made on study design or type/mechanism of acute soft tissue injury. Relevant outcomes were any physiological, cellular or molecular measurement associated with inflammation; recorded before injury, and up to one week post-injury. No restrictions were made on the type/dosage of cryotherapy intervention. 
Table 1 provides details of the cryotherapy interventions and reported outcomes across studies. Qualitative comparisons were made and results were grouped and discussed by outcome.

\section{Secondary Cell Injury}

Perhaps the most commonly cited rationale for applying ice after acute soft tissue injury relates to the 'secondary injury model'. ${ }^{3}$ This is based on the premise that after an initial trauma (e.g. muscle strain or contusion), the patho-physiological events associated with acute inflammation can induce secondary damage to cells around the injury site. Of particular concern is that this can involve collateral damage to healthy cells not injured in the initial trauma. This phenomenon is known as secondary cell injury, and may be caused by both enzymatic and ischaemic mechanisms. ${ }^{4}$ One of the most important cellular effects associated with cryotherapy is its potential to reduce the metabolic rate of tissue at, and surrounding the injury site. This reduction in metabolic demand may allow the cells to better tolerate the ischaemic environment in the immediate phases after injury thus minimizing the potential for secondary cell injury or death.

Table 1 Details of cryotherapy intervention and reported outcomes

\begin{tabular}{|c|c|c|c|c|}
\hline Author & $\begin{array}{l}\text { Details of cryotherapy } \\
\text { intervention }\end{array}$ & Directness of cooling & $\begin{array}{l}\text { Time after injury } \\
\text { of ice initiation }\end{array}$ & $\begin{array}{l}\text { Outcomes } \\
\text { (blinded assessor } \mathrm{Y} / \mathrm{N} \text { ) }\end{array}$ \\
\hline Osterman et al. ${ }^{5}$ & $\begin{array}{l}\text { CWI (ice and isotonic } \\
\text { saline); duration up to } \\
13 \text { hours (until ATP } \\
\text { depletion) }\end{array}$ & $\begin{array}{l}\text { Amputated limb with } \\
\text { a single layer of } \\
\text { plastic wrap (mean } \\
\text { intramuscular } \\
\text { temperature: } 1.2^{\circ} \mathrm{C} \text { ) }\end{array}$ & $\begin{array}{l}\text { Immediately post } \\
\text { amputation }\end{array}$ & $\begin{array}{l}\text { ATP/PCr } \\
\text { depletion (N) }\end{array}$ \\
\hline Sapega et al. ${ }^{6}$ & $\begin{array}{l}\text { CWI (isotonic saline at } \\
1,10,15 \text { and } 22^{\circ} \mathrm{C} \text { ); } \\
\text { duration } 45 \text { minutes, up to } \\
13 \text { hours }\end{array}$ & $\begin{array}{l}\text { Amputated limb } \\
\text { with a single layer of } \\
\text { plastic wrap } \\
\text { (intramuscular temperature as } \\
\text { low as } 0.5-1^{\circ} \mathrm{C} \text { ) }\end{array}$ & $\begin{array}{l}\text { Immediately post } \\
\text { amputation }\end{array}$ & $\begin{array}{l}\text { ATP/PCr depletion; } \\
\mathrm{pH}(\mathrm{N})\end{array}$ \\
\hline Farry et al. ${ }^{17}$ & $\begin{array}{l}\text { Crushed and compression, } \\
20 \text { minutes } \times 2\end{array}$ & Intact skin & Immediate (likely) & $\mathrm{IHA}(\mathrm{Y})$ \\
\hline Hurme et al. ${ }^{18}$ & $\begin{array}{l}\text { Cold pack with } \\
\text { compression and elevation; } \\
5 \text { minutes every } 14 \times 4\end{array}$ & $\begin{array}{l}\text { Intact skin (lowest } \\
\text { temperature recorded } \\
\text { in deep muscle: } 20^{\circ} \mathrm{C} \text { ) }\end{array}$ & Immediate & $\mathrm{IHA}(\mathrm{Y})$ \\
\hline Smith et al. ${ }^{22}$ & $\begin{array}{l}\text { Ice cylinders; } \\
20 \text { minutes } \\
\text { every } 6 \text { hours } \times 3\end{array}$ & Intact unshaven skin & Immediate (likely) & $\begin{array}{l}\text { Intravital microscopy } \\
\text { with MC }(Y) \\
\text { Laser Doppler } \\
\text { fluxmetry }\end{array}$ \\
\hline Curl et al. ${ }^{29}$ & $\begin{array}{l}\text { Ice cylinders; } \\
20 \text { minutes } \\
\text { every } 6 \text { hours for } 2 \text { days }\end{array}$ & Intact skin & 5 minutes & $\begin{array}{l}\text { Intravital } \\
\text { microscopy } \\
\text { with MC } \\
\text { Laser fluxmetry (N) }\end{array}$ \\
\hline Dolan et al. ${ }^{30}$ & $\begin{array}{l}\mathrm{CWI} \text { in } 12.8-15.6^{\circ} \mathrm{C} \\
30 \text { minutes } \times 4\end{array}$ & $\begin{array}{l}\text { CWI to intact } \\
\text { shaved limbs }\end{array}$ & 5 minutes & $\begin{array}{l}\text { Water } \\
\text { displacement }(\mathrm{N})\end{array}$ \\
\hline Merrick et al. ${ }^{7}$ & $\begin{array}{l}\text { Ice pack with elastic tape; } \\
5 \text { hours }\end{array}$ & Unshaven intact skin & Immediate (likely) & $\begin{array}{l}\text { Biochemical } \\
\text { assay }(N)\end{array}$ \\
\hline Westermann et al. ${ }^{13}$ & $\begin{array}{l}\text { Ice cold saline solution; } \\
1 \text { hour duration }\end{array}$ & $\begin{array}{l}\text { Through MC, } \\
\text { muscle surface } \\
\text { temperature } \\
\text { decreased to } 10 \pm 2^{\circ} \mathrm{C}\end{array}$ & Immediate & $\begin{array}{l}\text { Intravital } \\
\text { microscopy } \\
\text { with MC (N) }\end{array}$ \\
\hline Deal et al. ${ }^{31}$ & $\begin{array}{l}\text { Cylinder of ice to skin side } \\
\text { of MC; } 20 \text { minutes }\end{array}$ & Unshaven intact skin & 15 minutes & $\begin{array}{l}\text { Intravital } \\
\text { fluorescent } \\
\text { microscopy with } \\
\text { MC (N) }\end{array}$ \\
\hline Dolan et al. ${ }^{30}$ & $\begin{array}{l}\mathrm{CWI} \text { at } 12.8^{\circ} \mathrm{C} \text {; } 3 \text { hours, } \\
\text { followed by } 1 \text { hour rest }\end{array}$ & $\begin{array}{l}\text { CWI intact } \\
\text { shaven limbs }\end{array}$ & 5 minutes & $\begin{array}{l}\text { Water } \\
\text { displacement (N) }\end{array}$ \\
\hline Lee et al. ${ }^{14}$ & Saline at $3^{\circ} \mathrm{C} ; 10$ minutes & $\begin{array}{l}\text { Cooling directly } \\
\text { onto exposed } \\
\text { muscle surface }\end{array}$ & 5 minutes & $\begin{array}{l}\text { Intravital } \\
\text { microscopy (N) } \\
\text { Real time laser } \\
\text { scanning }\end{array}$ \\
\hline Schaser et al. ${ }^{15}$ & Saline at $8^{\circ} \mathrm{C} ; 20$ minutes & $\begin{array}{l}\text { Direct to surgically } \\
\text { exposed muscle } \\
\text { (muscle surface } \\
\text { temperature } \\
\text { cooled to } 10^{\circ} \mathrm{C} \text { ) }\end{array}$ & Immediate (likely) & $\begin{array}{l}\text { Intravital } \\
\text { microscopy } \\
\text { IHA (Y) }\end{array}$ \\
\hline Schaser et al. ${ }^{16}$ & Saline at $8^{\circ} \mathrm{C} ; 6$ hours & $\begin{array}{l}\text { Shaven intact skin } \\
\text { (muscle surface } \\
\text { temperature } \\
\text { cooled to } 10^{\circ} \mathrm{C} \text { ) }\end{array}$ & Immediate (likely) & $\begin{array}{l}\text { Intravital microscopy } \\
\text { IHA }(Y)\end{array}$ \\
\hline
\end{tabular}

Note: CWI, cold water immersion; IHA, immunohistological analysis; MC, microvascular chamber; ATP, adenosine triphosphate; PCr, phosphocreatine.

Immediate (likely): although not stated specifically, it was likely based on the experimental set-up. 
Evidence to support secondary injury theory is based largely on studies of limb preservation. Sapega and colleagues ${ }^{5,6}$ used phosphorous-31 nuclear magnetic resonance imaging to monitor cellular metabolism in ischaemic (amputated) cat limbs, stored for up to 10 hours, at a range of temperatures between 22 and $1{ }^{\circ} \mathrm{C}$. Limbs were removed at hourly intervals for rescanning; overall, results showed that muscle cells survived better at lower muscle temperatures. This was exemplified by lower levels of adenosine triphosphate (ATP) and phosphocreatine depletion, and lower levels of acidosis, during the period of ischaemia. Of note, these effects appeared to be reversed at more extreme muscle temperatures reductions below $5^{\circ} \mathrm{C}$. This was attributed to extreme temperature reductions causing inhibition of the calcium pump of the muscle's sarcoplasmic reticulum. ${ }^{6}$

In a more recent and related study, Merrick and colleagues $^{7}$ tried to quantify the effect of cryotherapy on mitochondrial function after injury. Specifically they measured the activity of the mitochondrial enzyme, cytochrome c oxidase, after experimental crush injury; comparing outcomes in cold treated and untreated muscle tissue. Fitting with the 'secondary injury model', 5 hours of continuous cooling with a crushed ice pack inhibited the loss of mitochondrial oxidative function after injury when compared to the untreated controls. Although the model used by Merrick et al. ${ }^{7}$ is not directly determining the effects of cryotherapy on the inflammatory process or muscle injury per se, it is the first study to have taken a novel approach to indirectly assess the effects of secondary generated free radicals, and their possible interference with enzymes controlling oxidative phosphorylation (cytochrome $\mathrm{c}$ oxidase) and thus ATP production after injury.

\section{White Blood Cells (WBCs)}

When muscle or joint injury occurs, phagocytic white cells, such as neutrophils, monocytes, eosinophils ad macrophages become activated and dominate the inflammatory response in the early stages. Although these cells have a critical role in healing through their removal of necrotic debris and release of cytokines; ${ }^{8}$ they can also have a negative effect on soft tissue healing after injury. ${ }^{8,9}$ For example, white cell activation results in a series of reactions termed the 'respiratory burst' ${ }^{10}$ These reactions are a source of reactive oxygen species (ROS) such as superoxide $\left(\mathrm{O}_{2}^{-}\right)$, hydrogen peroxide $\left(\mathrm{H}_{2} \mathrm{O}_{2}\right)$ and hydroxyl $\left(\mathrm{OH}^{\cdot}\right)$; and hypochlorous acid (HOC1) which is a powerful antibacterial agent. In certain circumstances the production of ROS and antibacterial agents are important immune defense mechanisms; however, they can also be a potentially dangerous mechanism if inappropriately activated. For example, overproduction of ROS may cause unwanted collateral damage to adjacent tissues and surrounding molecules. ${ }^{11}$ This may be particularly likely in the event of a closed soft tissue injury such as an ankle sprain, which is not associated with bacteria or infection. Indeed, there is evidence that blocking the respiratory burst, using anti-CD11b antibody (M1/70), produces a three-fold reduction in myofibre damage in an animal model at 24 hours post-injury. ${ }^{12}$

Interestingly, a number of animal models have studied the effect that crotherapy has on WBC behaviour after soft tissue injury. A popular approach has been to use fluorescent intravital microscopy ${ }^{13-16}$ to observe the effect that ice has on leukocyte activity within the microvasculature. These studies found a clear trend that icing significantly lowered the percentage of both adherent and rolling neutrophils after injury, in comparison to injured untreated tissue. This finding was consistent over the first 24 hours after injury. ${ }^{13-16}$

Other animal models ${ }^{7,15-18}$ have undertaken histological analysis on excised tissue after soft tissue injury. In each case, various staining techniques were used to identify leukocyte sub-types at the injury site. Again each study made comparisons between ice treated, and untreated injured tissue samples. Using an injured ligament model and assessor blinding, Farry et al. ${ }^{17}$ found that ice treated groups had lower levels of WBCs (polymorphs, lymphocytes and plasma cells) at 48 hours, in comparison to injured contra-lateral untreated limbs. Hurme et al., ${ }^{18}$ who also used blinded outcome analysis, found that at various time points post-injury, the ice treated animal tissue had lower levels of erythrocytes (1 hour), neutrophils (6 hours) and macrophages (at 24 hours) in comparison to the untreated control limbs. Although Schaser et al. ${ }^{15}$ also found cooling decreased neutrophilic granulocyte muscle infiltration, in comparison to control muscle, there were higher levels of macrophages. In a follow-up study ${ }^{16}$ using longer periods of cooling (5 hours), tissue analysis at 24 hours post trauma also found lower levels of neutrophilic granulocytes in the cold treated muscle.

Although the examination of adherent and rolling neutrophils following injury and cryotherapy may, in some instances, be beneficial, these models must be developed if we are to further our understanding in this area. It may be more relevant for future research to quantify the amount of direct neutrophil activation that occurs following injury. This approach may allow for estimation as to how much secondary cell and surrounding tissue damage and inflammation will likely occur. A popular marker that is commonly used to determine neutrophil activation is myeloperoxidase. 
This is produced by an increase in ROS activity and it has been successfully used in studies looking at free radical production and immune response after stretch injury in animal skeletal muscle. ${ }^{19}$

\section{Apoptosis}

Apoptosis is a programmed cell death. It is characterized by a cascade of biochemical events cumulating in altered cell morphology and eventual cell death. Although apoptosis is the normal means by which cells die at the end of their life span, its incidence may be affected by soft tissue injury. Higher numbers of apoptotic cells have been recorded around the edges of rotator cuff tears when compared to un-injured control muscles. ${ }^{20}$ The reasons for this increase have not yet been fully elucidated; however, the accumulation of reactive oxygen species in injured tissue (oxidative stress) could again play a significant role. ${ }^{21}$ Cell survival requires multiple factors, including appropriate proportions of molecular oxygen and various antioxidants. Although most oxidative insults can be overcome by the cell's natural defenses, sustained perturbation of this balance may result in apoptotic cell death.

There is limited evidence from animal models that cryotherapy can reduce the incidence of apoptosis after injury. Westermann et al. ${ }^{13}$ found that after chemically induced inflammation, the number of apoptotic muscle cells (quantified by the number with nuclear condensation and fragmentation) was significantly higher in untreated controls, when compared to the cryotherapy group (muscle surface cooled to $10^{\circ} \mathrm{C}$ ). This is an interesting finding as reduced levels of apoptosis may again represent a protective effect of cryotherapy after soft tissue injury. We can only postulate as to the reasons for this finding; however, this may be further evidence that cryotherapy can reduce inflammation and decrease secondary free radical production (from the respiratory burst), thereby causing less interference with important proteins and other cell metabolites that control apoptosis.

\section{Blood Flow and Oedema}

Acute soft tissue injury incurs a multitude of changes to the microvasculature. These include: increased vessel diameter; ${ }^{16,22}$ increased cell permeability and macromolecular leakage into the injured tissue ${ }^{16}$ and decreased tissue perfusion. ${ }^{13,15,16}$ Paradoxically, there is clear evidence that ice has a vasocontrictive response in human tissue based on impedance plethysmography outcomes. ${ }^{23,24}$ Recent studies ${ }^{25-28}$ also confirm that topical cooling has a similar effect on deep tissue haemodynamics, causing significant reductions in capillary blood flow, with facilitated venous capillary outflow in healthy humans. It is important to consider if cryotherapy can reverse the effects that soft tissue injury has on tissue haemodynamics using injured models. Again much of the evidence in this area is based on animal models.

Using intravital microscopy, some studies found that ice application did not significantly change capillary diameter, ${ }^{15,16}$ arteriole diameter, ${ }^{15,22,29}$ or capillary velocity after injury. ${ }^{15,16}$ In contrast, others found that ice either significantly increased ${ }^{15}$ or decreased ${ }^{13}$ arteriole diameter after injury.

There may be clearer patterns associated with venular diameters. Three studies ${ }^{14-16}$ reported smaller venular diameters in ice treated groups in comparison to injured (untreated) controls when measured at both the initial stages ${ }^{14,15}$ and at 24 hours ${ }^{16}$ postinjury. In two of these studies, ${ }^{14,16}$ the differences were significant, and in one case, venular diameter in the cold group had returned to pre-injury levels. ${ }^{16}$ Although this trend is supported with evidence that iced tissue also had higher levels of venular blood flow velocity in comparison to controls in the immediate stages post-injury, ${ }^{13-15}$ this trend was reversed at 24 hours post-injury.

There is also conflicting evidence on the effect that cryotherapy has on tissue perfusion post-injury. Using fluorescent microscopic assessment of the functional capillary density (length of erythrocyteperfused capillaries per observation area), three studies ${ }^{13,15,16}$ found that ice application significantly increases tissue perfusion after injury, in comparison to untreated injured controls. Again, in two cases, ${ }^{15,16}$ perfusion was restored to pre-injury levels. In contrast, based on laser Doppler imaging after injury, Curl et al. ${ }^{29}$ found that cooling had little effect on microvascular perfusion.

Using a related outcome measurement, Schaser and colleagues ${ }^{15,16}$ monitored intramuscular pressures in rat limbs after soft tissue injury, randomizing limbs to receive either cold saline, or no intervention. Lower intramuscular pressures [17.7 mm Hg (SD: 4.7)] were recorded at 1.5 hours post-injury in the cooling group (treated with 20 minutes of saline cooling), when compared to untreated controls [19.2 $\mathrm{mm} \mathrm{Hg}$ (SD: 3.1)]. Their follow-up study also found that longer periods of muscle cooling (5 hours) was associated with lower intramuscular pressures ${ }^{18}(95 \%$ CI: $5.5 \mathrm{~mm}$ $\mathrm{Hg}$ ) in comparison to untreated controls [26 (95\% CI: $1.9 \mathrm{~mm} \mathrm{Hg}$ )], at 24 hours post-injury.

\section{Limitation and Future Study}

There are a number of shortcomings associated with the current evidence base, particularly when we try to relate these findings to the injured human subject. Primarily, much of the research relies on animal models, applying various forms of cryotherapy after an induced 'crush type' soft tissue injury. Furthermore, 
in the majority of cases, the severity of the injury was controlled to avoid excessive haemorrhage or damage to major blood vessels, ${ }^{14,22,30,31}$ and is therefore not applicable to more serious soft tissue injuries presenting clinically. Similarly, the majority of studies have used a muscle contusion model, which on a mechanical, anatomical and pathological level, is different to a stretch type muscle injury or a ligament sprain.

The use of amputated or excised tissues samples has obvious drawbacks, when compared to models using perfused tissue. We must also consider that many of the in vivo models in this area used heavy anaesthesia on the animals throughout the experiment. Anaesthesia can alter tissue perfusion by as much as $38 \%,{ }^{22}$ which could clearly confound findings in an inflammatory study. Furthermore, an induced injury on an anaesthetized animal means that the muscle will be in a relaxed state. If the muscle is contracted at the time of contusion injury, which is usually the case in the sporting environment, we might expect a significantly different impact response and force displacement. ${ }^{32,33}$

It is clear that cryotherapy can have an effect on key inflammatory events at a cellular and physiological level. However, the relative benefits of these effects have yet to be fully elucidated and it is currently difficult to contextualize within a clinical model. Most of the work completed to date has focused on the animal model, perhaps due to its relative ease with regard to obtaining tissue. We must consider that the temperature reductions reported in animal tissues are extremely low (intra-muscular temperatures of $1-10^{\circ} \mathrm{C}$ ), and usually obtained within 15 minutes of injury. These tissue temperatures are not only difficult to replicate in a human model, but practically, cooling is usually initiated hours or days after injury, particularly within randomized controlled studies. Notwithstanding this, there needs be more emphasis placed on the effects of cryotherapy on inflammation and muscle injury using a human approach and model. Much work needs to be done using an array of peripheral and muscle specific markers to determine and quantify the inflammatory process per se. Considerable new information and knowledge within cryotherapy may be obtained by directly examining inflammatory related markers such as high sensitive C-reactive protein, tumour necrosis factor alpha, nuclear factor kappa B and interleukin molecules such as interleukin-6. Investigators should also be encouraged to examine markers of cellular oxidative stress in order to determine the relationship between primary and secondary free radical production (caused by soft tissue injury) and inflammation with and without cryotherapy application.
Considerations must also be given to the type of soft tissue affected. Muscle, ligaments and tendon tissue may also have different levels of tolerance when faced with post-injury ischaemia, and some may be more at risk of secondary cell injury and collateral damage. We must also clarify whether the potential benefits of cryotherapy are restricted to reducing or preventing secondary injury in cells not initially damaged by primary trauma, or if they could also target retardation of primary injury progression, i.e. rescuing cells that were involved in primary injury but not initially destroyed. ${ }^{4}$ This could also have considerable implications for clinical management of soft tissue injury.

\section{References}

1 Scott A, Khan KM, Roberts CR, Cook JL, Duronio V. What do we mean by the term 'inflammation'? A contemporary basic science update for sports medicine. $\mathrm{Br} \mathrm{J}$ Sports Med 2004;38(3):372-80.

2 Creaney L, Hamilton B. Growth factor delivery methods in the management of sports injuries: the state of play. Br J Sports Med 2008;42(5):314-20.

3 Knight KL. Cryotherapy in sports injury management. Champaign, IL: Human Kinetics; 1995. p. 3-98.

4 Merrick MA. Secondary injury after musculoskeletal trauma: a review and update. J Athl Train 2002;37(2):209-17.

5 Osterman AL, Heppenstall RB, Sapega AA, Katz M, Chance $\mathrm{B}$, Sokolow D. Muscle ischaemia and hypothermia: a bioenergetic study using ${ }^{31}$ Phosphorous Nuclear Magnetic Resonance Spectroscopy. J Trauma 1984;24(9):811-7.

6 Sapega AA, Heppenstall RB, Sokolow DP, Graham TJ, Maris $\mathrm{JM}$, Ghosh AK, et al. The bioenergetics of preservation of limbs before replantation. The rationale for intermediate hypothermia. J Bone Joint Surg Am 1988;70(10):1500-13.

7 Merrick MA, Rankin JM, Andres FA, Hinman CL. A preliminary examination of cryotherapy and secondary injury in skeletal muscle. Med Sci Sports Exerc 1999;31:1516-21.

8 Tidball JG. Inflammatory processes in muscle injury and repair. Am J Physiol Regul Integr Comp Physiol 2005;288(2):R345-53.

9 Toumi H, Best TM. The inflammatory response: friend or foe for muscle injury? Br J Sports Med 2003;37(4):284-6.

10 Blake DR, Allen RE, Lunec J. Free radicals in biological systems - a review orientated to inflammatory processes. $\mathrm{Br}$ Med Bull 1987;43(2):371-85.

11 Martinez-Cayuela M. Oxygen free radicals and human disease. Biochimie 1995;77(3):147-61.

12 Brickson S, Ji LL, Schell K, Olabisi R, St Pierre Schneider B, Best TM. M1/70 attenuates blood-borne neutrophil oxidants, activation and myofiber damage following stretch injury. J Appl Physiol 2003;95(3):969-76.

13 Westermann S, Vollmar B, Thorlacius H, Menger MD. Surface cooling inhibits tumor necrosis factor- $\alpha$-induced microvascular perfusion failure, leukocyte adhesion, and apoptosis in the striated muscle. Surgery 1999;126:881-9.

14 Lee H, Natsui H, Akimoto T, Yanagi K, Ohshima N, Kono I. Effects of cryotherapy after contusion using real-time intravital microscopy. Med Sci Sports Exerc 2005;37(7):1093-8.

15 Schaser KD, Stover JF, Melcher I, Lauffer A, Haas NP, Bail $\mathrm{HJ}$, et al. Local cooling restores microcirculatory hemodynamics after closed soft-tissue trauma in rats. J Trauma 2006;61:642-9.

16 Schaser KD, Disch AC, Stover JF, Lauffer A, Bail HJ, Mittlmeier T. Prolonged superficial local cryotherapy attenuates microcirculatory impairment, regional inflammation, and muscle necrosis after closed soft tissue injury in rats. Am J Sports Med 2007;35(1):93-102.

17 Farry PJ, Prentice NG, Hunter AC, Wakelin CA. Ice treatment of injured ligaments: an experimental model. N Z Med J 1980;91(651):12-4.

18 Hurme T, Rantanen J, Kalimo H. Effects of early cryotherapy in experimental skeletal muscle injury. Scand Med Sci Sports 1993;3:46-51. 
19 Brickson S, Hollander J, Corr DT, Ji LL, Best TM. Oxidant production and immune response after stretch injury in skeletal muscle. Med Sci Sports Exerc 2001;339(12):2010-5.

20 Yuan J, Murrell GA, Wei AQ, Wang MX. Apoptosis in rotator cuff tendonopathy. J Orthop Res 2002;20(6):1372-9.

21 Yuan J, Murrell GA, Trickett A, Wang MX. Involvement of cytochrome c release and caspase- 3 activation in the oxidative stress-induced apoptosis in human tendon fibroblasts. Biochim Biophys Acta 2003;1641(1):35-41.

22 Smith TL, Curl WW, Paterson Smith B, Holden MB, Wise T, Marr A, et al. New skeletal muscle model for the longitudinal study of alterations in microcirculation following contusion and cryotherapy. Microsurgery 1993;14:487-93.

23 Weston M. Taber C. Casagranda L. Cornwall M. Changes in local blood volume during cold gel pack application to traumatized ankles. J Orthop Sports Phys Ther 1994;19(4):197-9.

24 Karunakara RG, Lephart SM, Pincivero DM. Changes in forearm blood flow during single and intermittent cold application. J Orthop Sports Phys Ther 1999;29(3):177-80.

25 Knobloch K, Grasemann R, Spies M, Vogt PM. Midportion Achilles tendon microcirculation after intermittent combined cryotherapy and compression with cryotherapy alone: a randomized trial. Am J Sports Med 2008;36(11):2128-38.

26 Knobloch K, Kraemer R, Lichtenberg A, Jagodzinski M, Gosling T, Richter M, et al. Microcirculation of the ankle after Cryo/Cuff application in healthy volunteers. Int J Sports Med 2006;27(3):250-5.
27 Knobloch K, Grasemann R, Jagodzinski M, Richter M, Zeichen J, Krettek C. Changes of Achilles midportiontendon microcirculation after repetitive simultaneous cryotherapy and compression using a Cryo/Cuff. Am J Sports Med 2006;34(12):1953-9.

28 Knobloch K, Grasemann R, Spies M, Vogt PM. Intermittent KoldBlue cryotherapy of $3 \times 10 \mathrm{~min}$ changes mid-portion Achilles tendon microcirculation. $\mathrm{Br} \mathbf{J}$ Sports Med 2007;41(6):e4.

29 Curl WW, Smith BP, Marr A, Rosencrance E, Holden M, Smith TL. The effect of contusion and cryotherapy on skeletal muscle microcirculation. J Sports Med Phys Fitness 1997;37(4):279-86.

30 Dolan MG, Mychaskiw AM, Mattacola CG, Mendel FC. Effect of cool-water immersion and high voltage electric stimulation for 3 continuous hours on acute edema in rats. J Athl Train 2003;38(4):325-9.

31 Deal DN, Tipton J, Rosencrance E, Curl WW, Smith TL. Ice reduces edema. A study of microvascular permeability in rats. J Bone Joint Surg Am 2002;84-A(9):1573-8.

32 Garrett WE Jr, Safran MR, Seaber AV, Glisson RR, Ribbeck BM. Biomechanical comparison of stimulated and nonstimulated skeletal muscle pulled to failure. Am J Sports Med 1987;15:448-54.

33 Crisco JJ, Hentel KD, Jackson WO, Goehner K, Jokl P. Maximal contraction lessens impact response in a muscle contusion model. J Biomech 1996;29:1291-6. 